Tel.:

Fax:

E-Mail:

Main Research Interests (Key Words):

I agree to have my name, address and research interests published on the web site of the European Society for Microcirculation:

YES $\square \quad$ NO $\square \quad$ (If you don't tick here, we assume your agreement.)

Date:

Signature:

An application must be sponsored by two members of the European Society for Microcirculation.

and

Membership will be activated upon receipt of your payment.

For applicants not paying in USD the membership fee of the Society is $f$ 30.- payable every two years. Please enclose a cheque or bank draft for f 30.- payable to 'The European Society for Microcirculation'. If you send an Eurocheque, the Eurocheque Card number must be written on the back! Money may be transferred to our bank account \#00150472, Swiftcode RBOSGB2S with the Royal Bank of Scotland, Aberdeen Central Branch, 12 Golden Square, Aberdeen AB9 8DU, UK.

\section{Order Form}

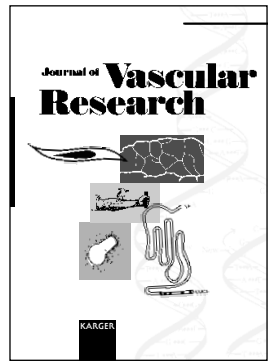

Members of the Society are reminded of the generous discount available on subscriptions to our sponsored journal, the Journal of Vascular Research (incorporating International Journal of Microcirculation). The subscription rate for 1999 and 2000 is each CHF $94.50+23.50$ shipment costs/USD $72.60+23.50$ shipment costs.

$\square$ Please send me a specimen copy

$\square$ I would like to order JVR on the above mentioned terms

S. Karger AG, P.O. Box CH-4009 Basel (Switzerland)

Fax +4161306 1234

Karger Publishers, Inc.

P.O. Box 529

E-Mail karger@karger.ch

PT 06085 (USA)

Fax (860) 675-7302
Return this form to:

Prof. Dr. Dick W. Slaaf, Treasurer

Department of Biophysics, Maastricht University

Cardiovascular Research Institute Maastricht, P.O. Box 616

NL-6200 MD Maastricht, The Netherlands

Applicants from America may make their payment in US dollars (to the equivalent of thirty pounds sterling which is 50 USD) and send their cheque to:

Associated Management Services, Attn.: Rebecca Loden 444 E. Algonquin Road, Arlington Heights, IL 60005, USA

\section{Payment:}
$\square$ Check enclosed
$\square$ Please bill me

Please charge this order to my credit card
$\square$ American Express
$\square$ Diners
$\square$ Eurocard
$\square$ MasterCard
$\square$ Visa

Card No::

Exp. date:

Name/Address (please print):

Date/Signature: 